\title{
Film Lovers' Delight
}

\author{
By Jan Uhde
}

Fall 2010 Issue of KINEMA

ANYBODY looking for an English DVD of the classic masterpiece combining Oscar Wilde's razor-sharp comments on Victorian society's hypocrisy with Lubitsch's cinematic sense and mise-en-scène had, until recently, limited options: He could purchase the 2007 Synergy Archives Series disc, described as a "very truncated and damaged edition", or buy the More Treasures From American Film Archives 1894-1931 set of three DVDs that includes a good transfer of the Lubitsch period drama. The latter is a valuable collection selling for USD 79.95 which nevertheless may be somewhat steep for somebody interested only in one film from the large collection.

A new alternative has emerged in the form of an excellent restoration of Lubitsch's Fan published in France for a relatively decent price. Language is no problem with this silent movie as the original English intertitles remain intact and the French subtitles may be turned off. The remaining hurdle, the pesky Region-2 encoding remains, however, many film lovers in other geographic areas have probably already found ways out of this predicament.

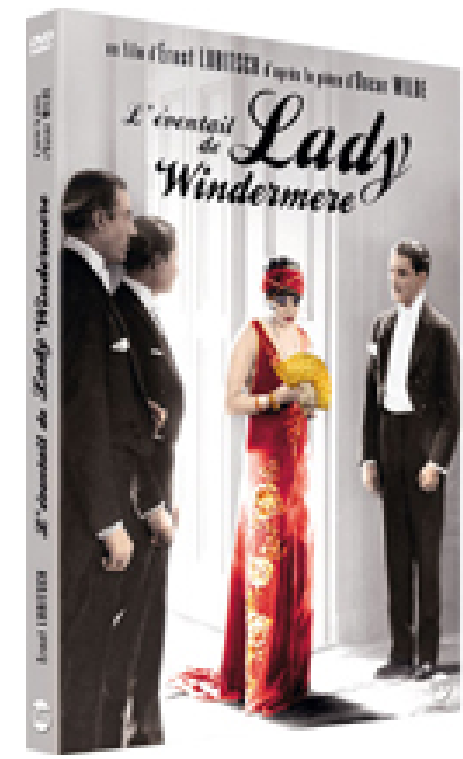

Figure 1: L'ÉVENTAIL DE LADY WINDERMERE DVD. (Lady Windermere's Fan directed by Ernst Lubitsch, 1925). I Monochrome, silent, with original English intertitles and removable French subtitles.) DVD Collector, éditions Montparnasse. ๆ PAL, Region 2, 79min. Booklet and supplements included. I (EUR 15.00.)

In 2010, the Annecy International Animation Film Festival celebrated its $50^{\text {th }}$ anniversary. Located in the picturesque small resort town in the French Alps not far from Geneva and bordering on a lake surrounded by mountains, Annecy has been presenting the best from the international animated production since 1960 .

To commemorate this important anniversary, the festival organized parallel events, one of them being the publication of a commemorative 256-page book Creators \& Creatures (Éditions Glénat), in collaboration with fifty personalities from the world of film animation, such as Michel Ocelot (Kirikou), Nick Park (Chicken Run), Matt Groening (The Simpsons), Bill Plympton (Mutant Aliens) and Jacques-Rémy Girerd (Raining Cats and Frogs). The Creatures $\&$ Creators exhibition was also installed at the Castle Museum. 
Animated cinema lovers worldwide will doubtlessly rejoice over the publication of the five-DVD anniversary collection of forty top animation films from Annecy's bountiful fifty-year history. The DVD set features mostly Grand Prize winners from 1960-2009, including Lev a pisnika (The Lion and the Song), Betislav Pojar, Grand prix 1960; The Breath, by Jimmy Murakami, Grand prix 1967 ex aequo with Klatki (Cages) by Miroslaw Kijowicz; Frank Film, Frank Mouris, Grand prix 1973; Afterlife, Ishu Patel, Grand prix 1979 ex aequo with Mr. Pascal, Alison de Vere; Možnosti dialogu (Possibilities of a Dialogue), Jan Švankmajer, Grand prix 1983; Village of Idiots, Eugene Fedorenko and Rose New love, Special Jury Prize 2000; and La Maison en petits cubes, Katô Kunio, Annecy Crystal 2008 (this award foreshadowing Katô's 2009 Oscar for the same film). The issue of this collection is a singular event which will, among other things, significantly improve general access to some of the key works of animated cinema. The only blemish is the absence of multi-language subtitles (English including) and the restrictive region coding.

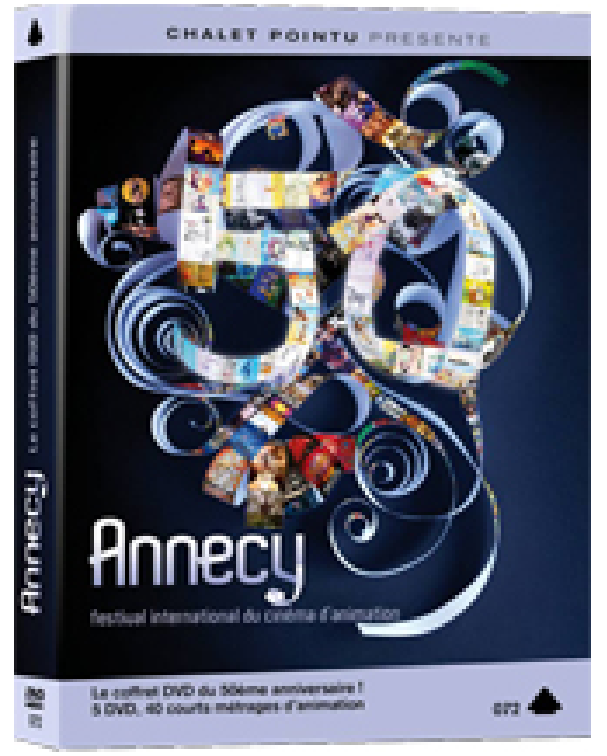

Figure 2: ANNECY, LE COFFRET DU 50ème ANNIVERSAIRE - DVD (5-disc set), France 2010. PAL-Region 2. Booklet. Language: French. Subtitles: French. 390min. (EUR 49.95)

\section{Author Information}

Jan UHDE is Professor Emer. (Film Studies) at the University of Waterloo, Ontario, Canada. Born in Brno, Czech Republic. Graduated (MA) from the Faculty of Arts, Masaryk University, Brno; PhD received at the University of Waterloo, Ontario, Canada. He taught at the University of Waterloo (1970-2012) where he founded a General and Honours BA program in Film Studies at the Department of Fine Arts.

Publications: Latent Images: Film in Singapore Second edition, with Yvonne Ng Uhde (Ridge Books, National University Press of Singapore, 2010); Latent Images: Film in Singapore, with Yvonne Ng Uhde (Oxford University Press, 2000); Latent Images: Film in Singapore CD-ROM (2003, co-author); Vision and Persistence: Twenty Years of the Ontario Film Institute (University of Waterloo Press, 1990) and Ontario Film Institute Programming Activities Index 1969-1989 (Toronto: Ontario Science Centre, 1990). He co-edited the Place in Space: Human Culture in Landscape (Proceedings from the Second International Conference of the Working Group "Culture and Landscape" of the International Association of Landscape Ecology, Pudoc Scientific Publishers, Wageningen, Holland, 1993). Jan Uhde has published articles and reviews in several countries (including Canada, USA, Germany, Italy), participated in international juries at film festivals and presented papers at international conferences in North America and Europe. In 1998/99, he was a visiting researcher at the School for Film and Media Studies, Ngee Ann Polytechnic, Singapore. 
His professional and research interests focus on Singapore cinema; the identification and distancing mechanisms of the film viewer; the non-authored modifications and manipulation of films; and specific aspects of film history, including the Central European cinema.

He founded KINEMA in 1993. 